\title{
Obtaining interspecific hybrids, and molecular analysis by microsatellite markers in grapevine
}

\author{
Mariane Ruzza Schuck(1), Luiz Antonio Biasi(1), Ada Michele Mariano(1), \\ Bernardo Lipski(1), Summaira Riaz ${ }^{(2)}$ and Michael Andrew Walker ${ }^{(2)}$
}

(1)Universidade Federal do Paraná, Departamento de Fitotecnia e Fitossanitarismo, CEP 80035-050 Curitiba, PR, Brazil. E-mail: schuck337@gmail.com, biasiufpr@gmail.com, adamichele@ibest.com.br, bernardolipski@hotmail.com (2)University of California, Department of Viticulture and Enology, Davis, CA 95616, USA. E-mail: snriaz@ucdavis.edu, awalker@ucdavis.edu

\begin{abstract}
The objective of this work was to assess the potential of interspecific hybridization of Vitis labruscana and Muscadinia rotundifolia by using artificial cross-pollinations. Microsatellite markers were used to confirm interspecific hybridizations and the identity of the parental genotypes. In crosses in which M. rotundifolia was used as the female parent, no true hybrids were obtained. In the reciprocal crosses, 114 seedlings were identified as true $V$. labruscana $\mathrm{x} M$. rotundifolia hybrids. Self-pollination occurred in direct and in reciprocal crosses. The crossings between 'Bordo' x 'Carlos', 'Magnolia', 'Regale' and 'Roanoke', and between 'Isabel' x 'Bountiful', 'Carlos', 'Magnolia', 'Regale' and 'Roanoke' were confirmed. The 15 markers evaluated showed that two M. rotundifolia parental genotypes had the same fingerprint profile, indicating a likely planting error. The success of hybridization depends mainly on the species and on the cultivar used as the female parent. Microsatellite markers are efficient to confirm the paternity of interspecific F1 hybrids and to determine the correct identity of M. rotundifolia cultivars.
\end{abstract}

Index terms: Muscadinia rotundifolia, Vitis labruscana, hybrid identification, interspecific crosses, SSRs.

\section{Obtenção de híbridos interespecíficos e análise molecular por marcadores microssatélites em videira}

Resumo - O objetivo deste trabalho foi avaliar o potencial da hibridação interespecífica entre Vitis labruscana e Muscadinia rotundifolia por meio de polinizações cruzadas artificiais. Marcadores microssatélites foram utilizados para confirmar as hibridizações interespecíficas e a identidade dos parentais. Nos cruzamentos em que M. rotundifolia foi utilizada como parental feminino, nenhum híbrido verdadeiro foi obtido. Nos cruzamentos recíprocos, 114 plântulas foram identificadas como verdadeiros híbridos de $V$. labruscana x M. rotundifolia. Ocorreu autopolinização nos cruzamentos diretos e nos recíprocos. Foram confirmados os cruzamentos 'Bordo' x 'Carlos', 'Magnolia', 'Regale' e 'Roanoke', e 'Isabel' x 'Bountiful', 'Carlos', 'Magnolia', 'Regale' e 'Roanoke'. Os 15 marcadores avaliados revelaram que dois parentais de M. rotundifolia apresentaram o mesmo perfil genético, o que indica provável erro de plantio. O sucesso da hibridização depende principalmente da espécie e da cultivar utilizada como parental feminino. Os marcadores microssatélites são eficientes para confirmar a paternidade de híbridos interespecíficos F1 e para determinar a correta identidade de cultivares de M. rotundifolia.

Termos para indexação: Muscadinia rotundifolia, Vitis labruscana, identificação híbrida, cruzamentos interespecíficos, SSRs.

\section{Introduction}

The use of rootstocks in viticulture is a widespread practice. Since the invasion by phylloxera [Daktulosphaira vitifoliae (Fitch, 1856)], grape growers began grafting susceptible Vitis vinifera $L$. fruiting cultivars onto rootstocks bred from resistant North American Vitis species, particularly V. rupestris Scheele, $V$. riparia Michx., $V$. berlandieri Planch. and $V$. labruscana L.H. Bailey. However, in addition to phylloxera resistance, a good rootstock must show adaptability to the local climate and soil conditions, besides easy rooting, affinity with the scion, good vegetative growth, longevity and resistance or tolerance to pests and pathogens (Reynolds \& Wardle, 2001).

Rootstock usage in the wine regions of Southern Brazil is dominated by different North American hybrid cultivars. Some of these cultivars are considered traditional, such as Solferino, SO4, Kober 5BB and 101-14 Mgt ( . berlandieri x $V$. riparia), whereas others were more recently introduced, such as Paulsen 1103 and $\mathrm{R} 99$ ( $V$. berlandieri $\mathrm{x}$ V. rupestris). Although these rootstocks have been recommended due to their resistance to Fusarium oxysporum Schlecht., they are the most susceptible to the main soil pest of this region, 
the Brazilian ground pearl [Eurhizococcus brasiliensis Hempel (Hemiptera: Margarodidae)] (Botton \& Colleta, 2010; Botton et al., 2010).

The muscadine genotypes [ $V$. rotundifolia Michx. Syn. M. rotundifolia (Michx.) Small] are resistant to the Brazilian ground pearl (Botton \& Colleta, 2010). This species has been classified as having the highest level of resistance to grape pests and disease (Kellow et al., 2002) and has consequently been used in many breeding programs worldwide to create resistant rootstocks. Although $M$. rotundifolia $(2 \mathrm{n}=40)$ is not used as a rootstock, due to its graft incompatibility with commercial cultivars of Vitis species $(2 \mathrm{n}=38)$ and to its inability to form roots from dormant cuttings (Goldy \& Onokpise, 2001), interspecific hybrids showing compatibility were created with Vitis species (Olmo, 1986). Some hybrids from these crosses, including VR039-16 and VR043-43 ( $V$. vinifera $\mathrm{x}$ $M$. rotundifolia), released by the grape breeding program at the University of California, Davis, CA, USA (Walker et al., 1991), are currently the main rootstocks used for management of the Brazilian ground pearl (Dalbó et al., 2007). However, 'VR043-43' is no longerrecommended for use in phylloxera-infested sites, since the resistance of its rootstock to Brazilian ground pearl was recently placed in doubt (De Césaro, 2008). Its full sibling 'VRO39-16' is only recommended for use in grapevine fanleaf virus-infected sites, as its long-term resistance to phylloxera is also questionable (Smith, 2010). Therefore, given that phylloxera resistance should be in the background of all new rootstocks and that the use of $V$. vinifera in rootstock development has almost invariably been disappointing, it is important to develop rootstocks with broader Brazilian ground pearl resistance and durable resistance to phylloxera, which can be obtained through breeding.

The hybridization of North American species with $M$. rotundifolia is an alternative to hybridization with $V$. vinifera. Among the many North American species, $V$. labruscana hybrids are well adapted to the wine regions of Southern Brazil. These hybrids are commonly planted with their own roots and show some resistance to soil pathogens, such as $F$. oxysporum (Garrido et al., 2004), besides adequate phylloxera resistance. However, these hybrids do not exhibit the high level of resistance to E. brasiliensis that M. rotundifolia cultivars do.
In breeding, molecular markers have been used as a tool to reduce the time required to develop a new cultivar. Among the various uses of molecular markers, the identification of true hybrids is an extremely useful tool in breeding programs. Therefore, the use of molecular markers to identify plants from crosses is highly important, so that plants from self or undesirable crosses can be identified and discarded in the F1 generation (Cordeiro et al., 2006).

The objective of this work was to assess the potential of interspecific hybridization of $V$. labruscana and $M$. rotundifolia by using artificial cross-pollinations.

\section{Materials and Methods}

All crosses were done at the Estação Experimental do Canguiri, of Universidade Federal do Paraná, Pinhais, PR, Brazil $\left(25^{\circ} 25^{\prime} \mathrm{S}, 4^{\circ} 08^{\prime \prime} \mathrm{W}\right.$, at $930-\mathrm{m}$ altitude), and at the Estação Experimental de Videira, Videira, $\mathrm{SC}$, Brazil $\left(27^{\circ} 0^{\prime} 5^{\prime \prime} \mathrm{S}, 51^{\circ} 7^{\prime} 60^{\prime \prime} \mathrm{W}\right.$, at $750-\mathrm{m}$ altitude) and at the Estação Experimental de Campos Novos, Campos Novos, Santa Catarina, Brazil (27 $23^{\prime} 60^{\prime \prime S}$, $51^{\circ} 12^{\prime} 0^{\prime \prime} \mathrm{W}$, at $947-\mathrm{m}$ altitude), of Empresa de Pesquisa Agropecuária e Extensão Rural de Santa Catarina (Epagri). The controlled crosses were made in both directions between $M$. rotundifolia cultivars: Bountiful, Carlos, Magnolia, Magoon, Regale and Roanoke, and V. labruscana cultivars: Bordo, Goethe, Isabel, Marta and Niagara Rosada, in 2008 and 2009. Sixty crosses were made. The number of controlled artificial pollinations varied among the crosses depending on the availability of flowers (Tables 1 and 2). Simple sequence repeat (SSR) markers were used to confirm the paternity of the putative hybrids and to authenticate the identity of the parental genotypes.

The controlled crosses were performed according to Leão \& Borges (2009). The female parents were emasculated before anthesis and bagged with paper bags to avoid contamination from unwanted pollen. The pollen was collected from flower clusters before anthesis in the morning, eliminating open flowers. The anthers were separated from the calyptra with a sieve, placed in petri dishes and dried at room temperature (20 to $25^{\circ} \mathrm{C}$ ) for three days. The pollen was placed in small bottles, labeled and stored in a desiccator with silica gel at $4^{\circ} \mathrm{C}$. Pollination was done with a brush for three consecutive days when the stigmas of the female 
parents were receptive, and the inflorescences were covered with paper bags.

Due to uneven maturation, the berries were harvested individually from January to April in both years. The seeds were extracted by forcing the fruits through a sieve, washed with water to remove the pulp, treated with a fungicide solution of Cercobin $2 \mathrm{~g} \mathrm{~L}^{-1}$ and then placed in moist media of sterilized vermiculite in petri dishes and stratified at $4{ }^{\circ} \mathrm{C}$ for a period of 75 days to break dormancy. Seeds were planted in seedling trays containing a steam-sterilized commercial substrate of Plantmax. When the first true leaves of seedlings appeared, they were transferred to individual pots $\left(125 \mathrm{~cm}^{3}\right)$, containing a mixture of 2 Plantmax:1 soil :1 humus: 1 vermiculite, and kept in the greenhouse.

Lyophilized leaf tissue of the parental genotypes and putative F1 hybrids was homogenized with DNA extraction buffer in plastic bags using a Homes 6 mechanical homogenizer (Bioreba, Longmont, CO, USA). DNA was extracted with a modified CTAB (hexadecyltrimethylammonium bromide) procedure (Riaz et al., 2004). In the final step, DNA pellets were suspended in $100 \mu \mathrm{L} 1 \mathrm{X}$ Tris-EDTA buffer and stored at $-20^{\circ} \mathrm{C}$. The integrity of the DNA was visualized on $1.2 \%$ agarose gel.

To analyze the extent of polymorphism of SSR markers in the parental genotypes, a set of 20 SSRs were tested on the $M$. rotundifolia and $V$. labruscana cultivars. A quality score, A, B, C or D, was given to each marker: Score A was given to four primer pairs (UDV41, UDV43, VrZAG62 and VVIN75) of good quality, displaying clear single band patterns easily scorable in both parents; score B to four medium quality markers (VVIM11, VVIC72, VVMD5 and VVMD31), displaying smears and fainter bands occasionally difficult to read; score C to three markers (UDV76, UDV111 and VVIP16), displaying multiband profiles; and score D to ten markers (UDV35, UDV111, VVIV05, VVIV21,UDV32,UDV35,UDV67,UDV124,VVIB68 and NVMCNG), producing smears, non-reproducible bands or no products. The four markers with score A were run on the entire populations to confirm the hybrid origin of the progenies. To verify the identity of the parental genotypes used in the crosses, the molecular profile of five $M$. rotundifolia cultivars was compared to the Grape DNA Identification Reference Database (Foundation Plant Services, University of California, Davis, CA, USA) with 15 SSR markers.
However, 'Roanoke' was not analyzed due to its absence in the reference database. DNA fingerprinting of the $V$. labruscana cultivars was done in a previous study by Schuck et al. (2009). The SSR markers used in the present study were VVS2, VVMD5, VVMD7, VVMD27, VVMD31, VVMD32, VrZag62, VrZag79, VMC4f3.1, VMC8g9, VMC7f2, VMC3df, VMC5a1, VMC5h2 and UDV108. PCR conditions used were described by Riaz et al. (2004). PCR reactions were carried out in $10 \mu \mathrm{L}$ reaction mixtures containing 5 pmol of each primer, $2.5 \mathrm{mmol} \mathrm{L}^{-1}$ of each dNTP, $1 \mu \mathrm{L} 10 \mathrm{X}$ gold PCR buffer (Perkin Elmer Inc., Wellesley, MA, USA), 0.5 unit AmpliTaq Gold DNA polymerase (Perkin Elmer Inc., Wellesley, MA, USA), $2 \mathrm{mmol} \mathrm{L}^{-1}$ of $\mathrm{MgCl}_{2}$ solution and $10 \mathrm{ng}$ of genomic DNA. Temperature cycling for PCR was carried out on either a Peltier Thermal Cycler-200 (MJ Research, Inc., Waltham, MA, USA) or on a Bio-Rad iCycler (Bio-Rad Laboratories, Hercules, CA, USA). The following cycling program was used: denaturation of DNA and activation of Taq DNA polymerase at $95^{\circ} \mathrm{C}$ for $10 \mathrm{~min}$; 35 cycles of amplification distributed in $45 \mathrm{~s}$ at $94^{\circ} \mathrm{C}, 45 \mathrm{~s}$ at $56^{\circ} \mathrm{C}$ and $1 \mathrm{~min}$ at $72^{\circ} \mathrm{C}$; final extension of $10 \mathrm{~min}$ at $72^{\circ} \mathrm{C}$; and cooling at $4{ }^{\circ} \mathrm{C}$. To separate amplification products, PCR reactions were mixed with denaturing dye $(98 \%$ formamide, $10 \mathrm{mmol} \mathrm{L}^{-1}$ EDTA, $0.05 \%$ bromophenol blue and xylene cyanol) and heated at $94^{\circ} \mathrm{C}$ for 2 min before loading on a $5 \%$ polyacrylamide sequencing gel. Gels were run at constant $70 \mathrm{~W}$ for 2-3 hours depending on allele sizes. Samples were visualized by silver staining with a commercial kit (Promega, Madison, WI, USA). Assuming Mendelian inheritance of the SSR loci, each of the analyzed progeny genotypes was considered to be a hybrid when one of the two SSR alleles amplified with each locus was common to the alleles in the maternal genotype and the other was the same as one of the SSR alleles found in the paternal genotype. All gels were scanned and stored in a digital archive.

\section{Results and Discussion}

In 2008, 30 cross combinations were made between six $M$. rotundifolia cultivars; Bountiful, Carlos, Magnolia, Magoon, Regale and Roanoke, and five V. labruscana cultivars: Bordo, Goethe, Isabel, Marta and Niagara Rosada. A total of 14,775 flowers were pollinated with $V$. labruscana pollen and 217 berries 
(1.5\% fruit set) were obtained. From these berries, 427 seeds were extracted and 236 germinated (Table 1). The number of berries obtained compared to the total flowers pollinated was extremely low, indicating that the crosses were very inefficient. Therefore, crosses using $M$. rotundifolia as the seed parent were not repeated in 2009. In 2008 and 2009, the reciprocals $V$. labruscana $\times$ M. rotundifolia were also made, and 9,398 V. labruscana flowers were pollinated producing

Table 1. Number of pollinated flowers, fruit set and number of surviving seedlings from the crosses between six Muscadinia rotundifolia cultivars, as the female parent, and five Vitis labruscana cultivars, as the male parent, at the Estação Experimental do Canguiri, Pinhais, PR, Brazil, and at the Estação Experimental de Videira, SC, Brazil, in 2008.

\begin{tabular}{|c|c|c|c|c|c|}
\hline $\begin{array}{l}\text { Vitis labruscana cultivar } \\
\text { as male parent }\end{array}$ & $\begin{array}{c}\text { № of } \\
\text { emasculations }\end{array}$ & $\begin{array}{l}\text { № of } \\
\text { berries }\end{array}$ & $\begin{array}{c}\text { Fruit } \\
\text { set }(\%)\end{array}$ & $\begin{array}{l}\text { № of } \\
\text { seeds }\end{array}$ & $\begin{array}{c}\text { № of } \\
\text { seedlings }\end{array}$ \\
\hline & \multicolumn{5}{|c|}{ M. rotundifolia 'Bountiful' as female parent } \\
\hline Bordo & 720 & 16 & 2.2 & 39 & 32 \\
\hline Goethe & 560 & 1 & 0.2 & 1 & 1 \\
\hline Isabel & 560 & 22 & 3.9 & 47 & 38 \\
\hline Marta & 720 & 12 & 1.7 & 29 & 25 \\
\hline \multirow[t]{2}{*}{ Niagara Rosada } & 560 & 7 & 1.3 & 13 & 10 \\
\hline & \multicolumn{5}{|c|}{$M$. rotundifolia 'Carlos' as female parent } \\
\hline Bordo & 50 & 0 & 0.0 & 0 & 0 \\
\hline Goethe & 300 & 6 & 2.0 & 17 & 14 \\
\hline Isabel & 150 & 0 & 0.0 & 0 & 0 \\
\hline Marta & 100 & 4 & 4.0 & 8 & 6 \\
\hline \multirow[t]{2}{*}{ Niagara Rosada } & 100 & 3 & 3.0 & 10 & 5 \\
\hline & \multicolumn{5}{|c|}{ M. rotundifolia 'Magnolia' as female parent } \\
\hline Bordo & 1,200 & 13 & 1.1 & 12 & 1 \\
\hline Goethe & 1,100 & 7 & 0.6 & 11 & 9 \\
\hline Isabel & 1,300 & 10 & 0.8 & 13 & 2 \\
\hline Marta & 1,000 & 6 & 0.6 & 19 & 9 \\
\hline \multirow[t]{2}{*}{ Niagara Rosada } & 1,300 & 12 & 0.9 & 8 & 3 \\
\hline & \multicolumn{5}{|c|}{ M. rotundifolia 'Regale $^{\prime(1)}$ as female parent } \\
\hline Bordo & 780 & 33 & 4.2 & 74 & 31 \\
\hline Goethe & 645 & 6 & 0.9 & 12 & 4 \\
\hline Isabel & 720 & 19 & 2.6 & 37 & 13 \\
\hline Marta & 630 & 15 & 2.4 & 31 & 12 \\
\hline \multirow[t]{2}{*}{ Niagara Rosada } & 480 & 10 & 2.1 & 14 & 5 \\
\hline & \multicolumn{5}{|c|}{ M. rotundifolia 'Roanoke' as female parent } \\
\hline Bordo & 360 & 4 & 1.1 & 8 & 3 \\
\hline Goethe & 360 & 2 & 0.6 & 3 & 1 \\
\hline Isabel & 360 & 1 & 0.3 & 2 & 2 \\
\hline Marta & 360 & 6 & 1.7 & 14 & 4 \\
\hline Niagara Rosada & 360 & 2 & 0.6 & 5 & 6 \\
\hline Total & 14,775 & 217 & 1.5 & 427 & 236 \\
\hline
\end{tabular}

${ }^{(1)}$ The results obtained in the crosses between Vitis labruscana cultivars and 'Magoon' were added to those of 'Regale', since the genetic profile of 'Magoon' matched with 'Regale' at all 15 markers, indicating that the genotype was misnamed at the time of introduction and that the same genotype was planted with different names.
416 berries (4.4\% fruit set), 1,040 seeds and 342 seedlings (Table 2).

DNA fingerprinting with the SSR loci UDV41, UDV43, VrZAG62 and VVIN75 indicated that, whenever $M$. rotundifolia was used as the female and $V$. labruscana as the male parent, the crosses were a complete failure, producing no true hybrids but only direct descendants of M. rotundifolia. From 342, in the reciprocal crosses, 114 seedlings, originated from nine

Table 2. Number of pollinated flowers, fruit set and number of surviving seedlings from the crosses between five Vitis labruscana cultivars, as the female parent, and six Muscadinia rotundifolia cultivars, as the male parent, at the Estação Experimental de Campos Novos and Videira, SC, Brazil, in 2008 and 2009.

\begin{tabular}{|c|c|c|c|c|c|}
\hline $\begin{array}{l}\text { Muscadinia rotundifolia } \\
\text { cultivar as male parent }\end{array}$ & $\begin{array}{c}\text { № of } \\
\text { emasculations }\end{array}$ & $\begin{array}{l}\text { № of } \\
\text { berries }\end{array}$ & $\begin{array}{c}\text { Fruit } \\
\text { set }(\%)\end{array}$ & $\begin{array}{l}\text { № of } \\
\text { seeds }\end{array}$ & $\begin{array}{c}\text { № of } \\
\text { seedlings }\end{array}$ \\
\hline & \multicolumn{5}{|c|}{ V. labruscana 'Bordo' as female parent } \\
\hline Bountiful & 65 & 0 & 0.0 & 0 & 0 \\
\hline Carlos & 325 & 21 & 6.5 & 48 & 7 \\
\hline Magnolia & 520 & 52 & 10.0 & 120 & 54 \\
\hline Regale $^{(1)}$ & 625 & 55 & 8.8 & 114 & 52 \\
\hline \multirow[t]{2}{*}{ Roanoke } & 715 & 10 & 1.4 & 35 & 30 \\
\hline & \multicolumn{5}{|c|}{ V. labruscana 'Goethe' as female parent } \\
\hline Bountiful & 94 & 0 & 0.0 & 0 & 0 \\
\hline Carlos & 105 & 0 & 0.0 & 0 & 0 \\
\hline Magnolia & 119 & 0 & 0.0 & 0 & 0 \\
\hline Regale $^{(1)}$ & 143 & 0 & 0.0 & 0 & 0 \\
\hline \multirow[t]{2}{*}{ Roanoke } & 86 & 0 & 0.0 & 0 & 0 \\
\hline & \multicolumn{5}{|c|}{ V. labruscana 'Isabel' as female parent } \\
\hline Bountiful & 250 & 4 & 1.6 & 5 & 1 \\
\hline Carlos & 300 & 33 & 11.0 & 71 & 16 \\
\hline Magnolia & 550 & 70 & 12.7 & 135 & 31 \\
\hline Regale $^{(1)}$ & 1,501 & 41 & 2.7 & 87 & 21 \\
\hline \multirow[t]{2}{*}{ Roanoke } & 450 & 7 & 1.6 & 16 & 9 \\
\hline & \multicolumn{5}{|c|}{ V. labruscana 'Marta' as female parent } \\
\hline Bountiful & 150 & 0 & 0.0 & 0 & 0 \\
\hline Carlos & 150 & 0 & 0.0 & 0 & 0 \\
\hline Magnolia & 100 & 0 & 0.0 & 0 & 0 \\
\hline Regale $^{(1)}$ & 150 & 1 & 0.6 & 2 & 1 \\
\hline \multirow[t]{2}{*}{ Roanoke } & 100 & 2 & 2.0 & 4 & 0 \\
\hline & \multicolumn{5}{|c|}{ V. labruscana 'Niagara Rosada' as female parent } \\
\hline Bountiful & 150 & 0 & 0.0 & 19 & 0 \\
\hline Carlos & 525 & 25 & 4.8 & 145 & 62 \\
\hline Magnolia & 450 & 52 & 11.6 & 110 & 36 \\
\hline Regale $^{(1)}$ & 675 & 45 & 6.6 & 129 & 22 \\
\hline Roanoke & 100 & 0 & 0.0 & 0 & 0 \\
\hline Total & 9,398 & 416 & 4.4 & 1,040 & 342 \\
\hline
\end{tabular}

${ }^{(1)}$ The results obtained in the crosses between Vitis labruscana cultivars and 'Magoon' were added to those of 'Regale', since the genetic profile of 'Magoon' matched with 'Regale' at all 15 markers, indicating that the genotype was misnamed at the time of introduction and that the same genotype was planted with different names. 
different crosses, were identified at all four markers as true $V$. labruscana x M. rotundifolia hybrids (Table 3 ).

In the crosses in which 'Isabel' was the female parent, 65 true hybrids were identified (Figure 1). All the $M$. rotundifolia cultivars used to pollinate 'Isabel'

Table 3. Percentage of interspecific Vitis hybrids from the crosses between two Vitis labruscana cultivars, as female parent, and five Muscadinia rotundifolia cultivars, as male parent, confirmed by SSR markers (UDV41, UDV43, VrZAG62 and VVIN75).

\begin{tabular}{lccc}
\hline $\begin{array}{l}\text { Muscadinia rotundifolia } \\
\text { cultivar as male parent }\end{array}$ & $\begin{array}{c}\text { № of plants } \\
\text { evaluated }\end{array}$ & $\begin{array}{c}\text { № of true } \\
\text { hybrids }\end{array}$ & $\begin{array}{c}\text { True } \\
\text { hybrids (\%) }\end{array}$ \\
\hline Carlos & 7 & 3 labruscana & 'Bordo' as female parent \\
Magnolia & 54 & 16 & 42.9 \\
Regale & 22 & 15 & 29.6 \\
Roanoke & 30 & 15 & 68.9 \\
Total & 113 & 49 & 50.0 \\
\hline & V. labruscana & 'Isabel' as female parent \\
Bountiful & 1 & 1 & 100 \\
Carlos & 16 & 11 & 68.8 \\
Magnolia & 31 & 27 & 87.1 \\
Regale & 20 & 17 & 85.0 \\
Roanoke & 9 & 9 & 100.0 \\
Total & 77 & 65 & 84.4 \\
\hline Total & 190 & 114 & 60 \\
\hline
\end{tabular}

generated true hybrids, except 'Magoon'. The largest population of $V$. labruscana $\mathrm{x} M$. rotundifolia consists of 27 seedlings ( $87.1 \%$ true hybrids) and is a cross of 'Isabel' x 'Magnolia'. From the cross 'Isabel' x 'Regale', 20 seedlings were evaluated and $17 \mathrm{~F} 1$ hybrids were confirmed. The cross 'Isabel' x 'Carlos' yielded 16 seedlings, of which 11 were true hybrids (68.8\%). The highest percentage of hybrid formation was observed in the crosses 'Isabel' x 'Roanoke' and 'Isabel' x 'Bountiful', with 100\% true hybrids. From these crosses, only nine and one seedlings were analyzed, respectively (Table 3 ).

The crosses between the female parent 'Bordo' with M. rotundifolia cultivars produced 49 true hybrids (43.4\%) (Figure 2). Of the six cultivars used as the male parent with 'Bordo', two ('Bountiful' and 'Magoon') did not produce progenies with the SSR profile expected for F1 interspecific hybrids. The percentage of hybrid formation was highest in the crosses 'Bordo' $\mathrm{x}$ 'Regale' and 'Bordo' x 'Roanoke', with 68.9 and 50\% true hybrids, respectively. The lowest percentage (29.6\%) of true hybrids originated from the cross 'Bordo' $\mathrm{x}$ 'Magnolia'. Out of the 54 individuals analyzed, 16 were confirmed as true hybrids. From the cross 'Bordo'

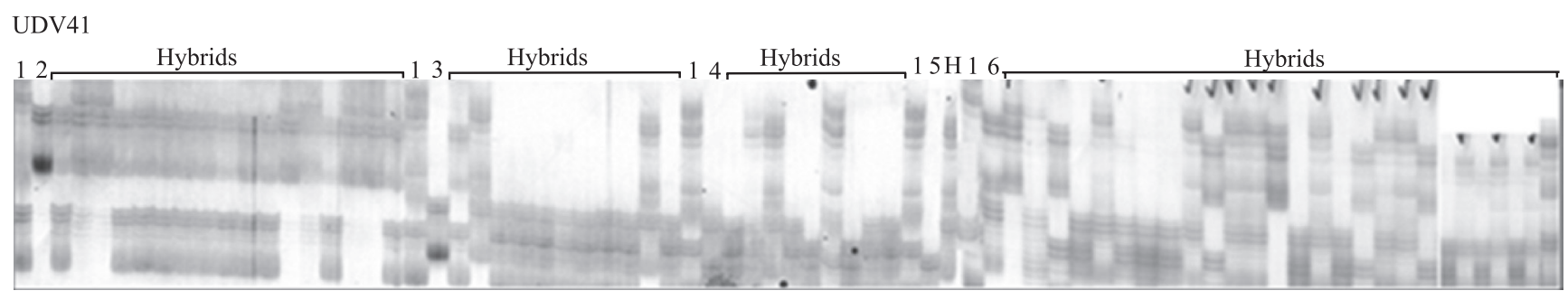

UDV43

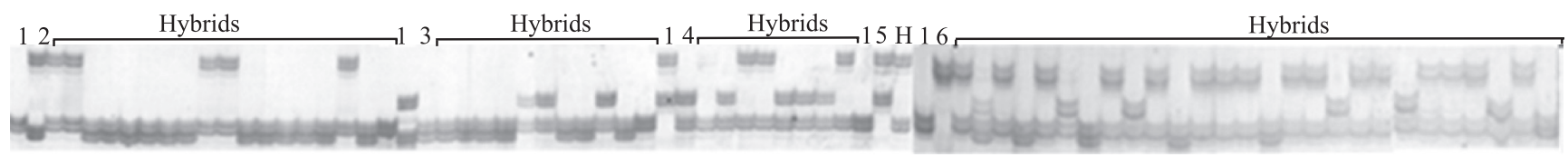

VVIN75

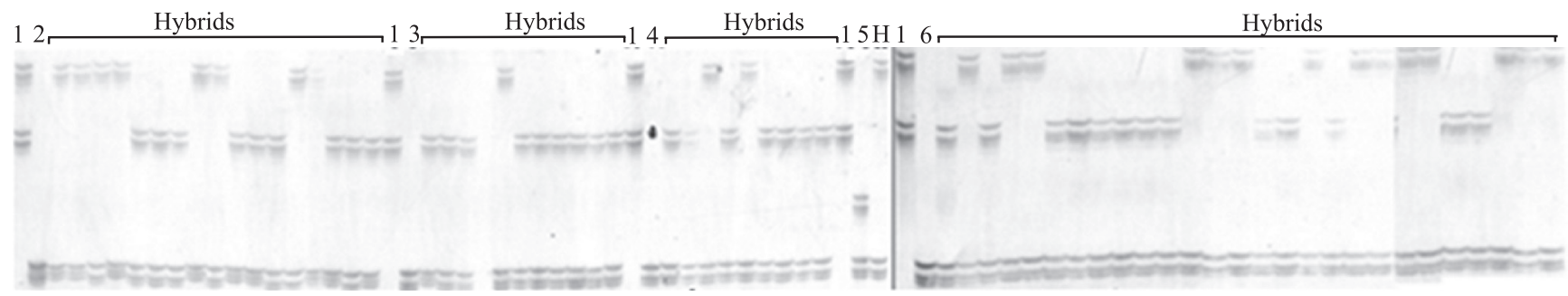

Figure 1. PCR amplification profile of the SSR markers UDV41 and UDV43 (Di Gaspero et al., 2005) and VVIN75 (Merdinoglu et al., 2005) in 'Isabel' (1), 'Regale' (2), 'Carlos' (3), 'Roanoke' (4), 'Bountiful' (5) and 'Magnolia' (6) followed by the true hybrids derived from each cross. $\mathrm{H}$, hybrid. 
x 'Carlos', seven F1 plants were evaluated and three hybrids were confirmed (42.9\%) (Table 3).

Though only five $V$. labruscana genotypes were used as female parents in the present study, a marked difference was observed between them in their crossability with $M$. rotundifolia. These results clearly indicate that the success of the interspecific crosses depends not only on the species and on the direction of the cross, but also on the genotypes of the species involved in the hybridization. Other authors showed that the $V$. vinifera cultivars used as the female genotype influenced the crossability with M. rotundifolia (Bouquet, 1980).

The chromosome difference between Vitis spp. $(2 \mathrm{n}=38)$ and $M$. rotundifolia $(2 \mathrm{n}=40)$ is considered the main reason for the low success of the crosses in both directions (Goldy \& Onokpise, 2001). However, in crosses involving $M$. rotundifolia as the maternal parent, the difficulties in obtaining hybrids are higher than in the reciprocal (Bouquet, 1980; Olmo, 1986). The failure in obtaining hybrid seedlings when $M$. rotundifolia serves as the female parent can be attributed to the inability of Vitis spp. pollen tubes to successfully penetrate M. rotundifolia styles and to fertilize the egg cells (Lu \& Lamikanra, 1996).
In addition to the genetic incompatibility between the species, phenological factors also limit the success of reciprocal crosses. In Southern Brazil, V. labruscana blooms from September to October, and $M$. rotundifolia from November to January. Because of this difference, in the present study, $V$. labruscana cultivars were double pruned, during their regular blooming period, to force them to bloom again so that fresh pollen from $M$. rotundifolia could be used in the flowers of V. labruscana.

Although fresh pollen was used to make these 60 crosses, crosses in both directions produced a high proportion of non-hybrids, all of which were the result of self-fertilization. Even though paper bags were placed over the pollinated flower clusters and the adjacent clusters on the same plant were eliminated to avoid contamination from unwanted pollen, wind could have deposited pollen on the emasculated clusters during the few seconds that the protective bags were removed to perform pollination. Therefore, bagging of flowers does not guarantee the lack of undesired pollinations (Neal \& Anderson, 2004). Moreover, shoot position and bunch location on the shoot in the developing canopy also influence flowering (Vasconselos et al.,

UDV41

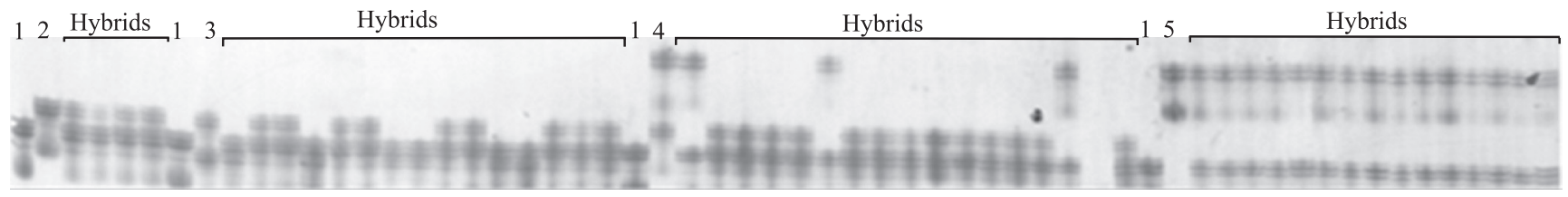

UDV43
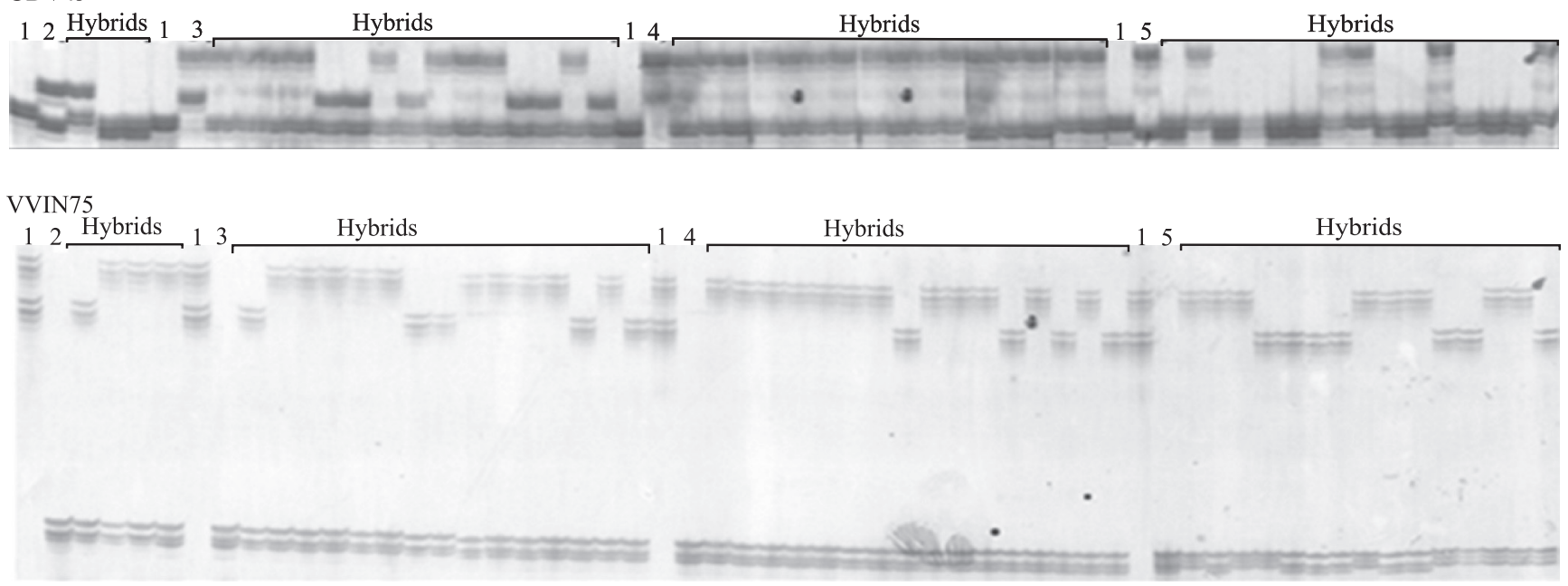

Figure 2. PCR amplification profile of the SSR markers UDV41 and UDV43 (Di Gaspero et al., 2005) and VVIN75 (Merdinoglu et al., 2005) in 'Bordo' (1), 'Carlos' (2), 'Roanoke' (3), 'Magnolia' (4) and 'Regale' (5) followed by the true hybrids derived from each cross. H, hybrid. 
2009). In the present study, the inflorescences used in the crosses were from the mid cane of the shoots.

The average high temperatures reported for both years $(2008 / 2009)$ in the three regions where the crosses were made (Pinhais, PR $-31^{\circ} \mathrm{C}$; Campos Novos, $\mathrm{SC}-26.5^{\circ} \mathrm{C}$; and Videira, $\mathrm{SC}-31^{\circ} \mathrm{C}$ ) may have induced early pollen maturation of the flower clusters near the end of the canes of the same plant and in the neighboring inflorescences of the same vine located a few meters away. This could have accelerated pollen drying and increased the chances of pollen being carried by the wind and being deposited on unprotected flowers of $M$. rotundifolia and $V$. labruscana before they bloomed. In addition, the role of insects as pollination agents cannot be rejected.

The use of microsatellite markers for the identification of true hybrids in the early stage of the selection process has shown to be a very useful tool. A high proportion of selfed plants were identified, which were discarded in the F1 generation, allowing for significant savings in resources, particularly time and space. In species with long breeding cycles, such as Vitis spp., the conventional process of hybrid identification by morphological differences is slow. Molecular tools may overcome these difficulties and open the way to new strategies for more efficient breeding.

The identification of the $V$. labruscana genotypes was part of a previous study, and the SSR profiles of the cultivars Bordo, Goethe, Isabel, Niagara Rosada and Marta were the same as those available in the data banks for the same cultivars using SSR markers VVS2, VVMD5, VVMD7, VVMD27, VrZag62 and VrZag79. Therefore, these cultivars were correctly identified (Table 4) (Schuck et al, 2009).

To confirm the identity of the $M$. rotundifolia parental genotypes, five cultivars were genotyped at 15 SSR loci. Consistent and reliable profiles were obtained for the five cultivars at all SSR markers. The genetic profile of the $M$. rotundifolia cultivars Bountiful, Carlos, Magnolia and Regale were identical to those of the reference database at all 15 SSR loci. However, 'Magoon' did not match the reference profile at the same SSR loci, but matched with 'Regale', indicating that the genotype was misnamed at the time of introduction and that the same genotype was planted under different names (Table 4).

The correct identification of accessions is a basic requirement for the coherent management of germplasm repositories and for the use of the germplasm in ongoing breeding programs. It is essential to identify the existence of synonyms, homonyms and naming errors to avoid future propagation and breeding errors. These mistakes are difficult to detect based on morphological descriptors, since they are highly influenced by environmental and developmental factors (Sefc et al., 2001). In contrast, SSRs markers have been used to solve problematic naming and for genetic diversity assessment (Leão \& Motoike,

Table 4. Allele sizes (bp) of Muscadinia rotundifolia and Vitis labruscana cultivars used as parents.

\begin{tabular}{|c|c|c|c|c|c|c|c|c|c|c|c|}
\hline \multirow[t]{2}{*}{ Locus } & \multicolumn{5}{|c|}{ M. rotundifolia } & \multicolumn{5}{|c|}{ V. labruscana ${ }^{(1)}$} & \multirow[t]{2}{*}{ Reference } \\
\hline & 'Bountiful' & 'Carlos' & 'Magnolia' & 'Magoon' & 'Regale' & 'Bordo' & 'Goethe' & 'Isabel' & 'Marta' & 'Niagara Rosada' & \\
\hline VVS2 & $153-153$ & $147-149$ & $147-147$ & $147-147$ & $147-147$ & $118-130$ & $120-130$ & $118-146$ & $120-146$ & $118-128$ & Thomas \& Scott (1993) \\
\hline VVMD5 & $230-246$ & $230-246$ & $230-230$ & $226-230$ & $226-230$ & $234-234$ & $230-236$ & $236-236$ & $234-234$ & $234-234$ & Bowers et al. (1996) \\
\hline VVMD7 & $235-235$ & $243-245$ & $243-245$ & $243-243$ & $243-243$ & $235-239$ & $235-247$ & $235-249$ & $235-249$ & $235-241$ & Bowers et al. (1996) \\
\hline VVMD27 & 199-199 & $197-215$ & $185-215$ & $185-197$ & 185-197 & $179-181$ & $181-183$ & $175-179$ & $179-181$ & $175-181$ & Bowers et al. (1999) \\
\hline VVMD31 & $246-250$ & $168-170$ & $170-210$ & $170-210$ & $170-210$ & $201-213$ & 203-209 & $201-213$ & 201-203 & 201-201 & Bowers et al. (1999) \\
\hline VVMD32 & 249-301 & 249-301 & 249-301 & 249-301 & 249-301 & $248-248$ & $246-252$ & $248-272$ & $248-248$ & $248-272$ & Bowers et al. (1999) \\
\hline VrZag62 & $215-223$ & $199-215$ & $199-215$ & 199-199 & 199-199 & $200-202$ & $190-204$ & $200-202$ & $200-202$ & 200-202 & Sefc et al. (1999) \\
\hline VrZag79 & $255-255$ & $257-287$ & $259-287$ & $255-259$ & $255-259$ & $247-247$ & $239-247$ & $237-247$ & $247-264$ & $237-259$ & Sefc et al. (1999) \\
\hline VMC4f3.1 & $222-222$ & $202-222$ & $208-222$ & $222-226$ & $222-226$ & $-(2)$ & - & - & - & - & Di Gaspero et al. (2000) \\
\hline VMC8g9 & $138-140$ & $136-140$ & $138-140$ & $135-138$ & $135-138$ & - & - & - & - & - & Adam-Blondon et al. (2004) \\
\hline VMC7f2 & $193-195$ & $193-193$ & $193-193$ & $193-195$ & $193-195$ & - & - & - & - & - & Adam-Blondon et al. (2004) \\
\hline VMC3df & $174-178$ & $172-178$ & $172-178$ & $170-172$ & $170-172$ & - & - & - & - & - & Adam-Blondon et al. (2004) \\
\hline VMC5a1 & $163-170$ & $163-170$ & $170-170$ & $170-170$ & $170-170$ & - & - & - & - & - & Adam-Blondon et al. (2004) \\
\hline VMC5h2 & $198-200$ & $194-212$ & $194-212$ & $194-212$ & $194-212$ & - & - & - & - & - & Adam-Blondon et al. (2004) \\
\hline UDV108 & $208-208$ & $208-208$ & $202-202$ & $202-220$ & $202-220$ & - & - & - & - & - & Di Gaspero et al. (2005) \\
\hline
\end{tabular}

${ }^{(1)}$ Cultivars analyzed in previous study by Schuck et al. (2009). ${ }^{(2)}$ SSRs not analyzed. 
2011), for parentage analysis (Tapia et al., 2007) and to develop genetic maps (Riaz et al., 2004).

\section{Conclusions}

1. The hybridization success between $V$. labruscana and $M$. rotundifolia depends on the species and on the cultivar used as the female parent.

2. Cultivars of $V$. labruscana can be successfully crossed with pollen from $M$. rotundifolia cultivars, but all reciprocal combinations fail to produce true hybrids.

3. Crosses between $V$. labruscana cultivar Isabel $\mathrm{x}$ M. rotundifolia cultivars Bountiful, Carlos, Magnolia, Regale and Roanoke are possible, as well as crosses between $V$. labruscana cultivar Bordo x M. rotundifolia cultivars Carlos, Magnolia, Regale and Roanoke, indicating that these species can be used in breeding programs.

4. SSR markers are efficient to confirm the paternity of interspecific F1 hybrids and to determine the correct identity of $M$. rotundifolia cultivars.

\section{Acknowledgments}

To Conselho Nacional de Desenvolvimento Científico e Tecnológico, for financial support; to Programa de Apoio a Planos de Reestruturação e Expansão das Universidades Federais and to Coordenação de Aperfeiçoamento de Pessoal de Nível Superior, for scholarships granted; to Empresa de Pesquisa Agropecuária e Extensão Rural de Santa Catarina and to Universidade Federal do Paraná, for support; and to Rong $\mathrm{Hu}$, from the University of California, for assistance with the SSR analysis.

\section{References}

ADAM-BLONDON,A.-F.; ROUX, C.; CLAUX, D.; BUTTERLIN, G.; MERDINOGLU, D.; THIS, P. Mapping 245 SSR markers on the Vitis vinifera genome: a tool for grape genetics. Theoretical and Applied Genetics, v.109, p.1017-1027, 2004.

BOTTON, M.; COLLETA, V.D. Avaliação da resistência de cultivares de Vitis rotundifolia à pérola-da-terra (Hemiptera: Margarodidae) na região sul do Brasil. Acta Scientiarum. Agronomy, v.32, p.213-216, 2010.

BOTTON, M.; MELO, G.W.B. de; OLIVEIRA, O.L.P. de; ONZI, I. Efeito da cobertura vegetal sobre a pérola-da-terra (Hemiptera: Margarodidae) na cultura da videira. Acta Scientiarum. Agronomy, v.32, p.681-684, 2010.
BOUQUET, A. Vitis x Muscadinia hybridization: a new way in grape breeding for disease resistance in France. In: INTERNATIONAL SYMPOSIUM ON GRAPE BREEDING, 3., 1980, Davis. Proceedings. Davis: University of California, 1980. p.42-61.

BOWERS, J.E.; DANGL, G.S.; MEREDITH, C.P. Development and characterization of additional microsatellite DNA markers for grape. American Journal of Enology and Viticulture, v.50, p.243-246, 1999.

BOWERS, J.E.; DANGL, G.S.; VIGNANI, R.; MEREDITH, C.P. Isolation and characterization of new polymorphic simple sequence repeat loci in grape (Vitis vinifera L.). Genome, v.39, p.628-633, 1996.

CORDEIRO, M.C.R.; PINTO, A.C. de Q.; RAMOS, V.H.V.; FALEIRO, F.G.; FRAGA, L.M.S. Utilização de marcadores RAPD e outros parâmetros na determinação de genitores em híbridos de mangueira. Revista Brasileira de Fruticultura, v.28, p.164-167, 2006.

DALBÓ, M.A.; PERUZZO, E.L.; SCHUCK, E. Alternativas de manejo para o controle do declínio da videira. Agropecuária Catarinense, v.20, p.58-61, 2007.

DE CÉSARO, A. Caracterizações histológica e fisiológica do ataque de pérola-da-terra (Eurhizococcus brasiliensis Wille, 1922) (Hemiptera: Margarodidade) em videiras. 2008. 89p. Dissertação (Mestrado) - Universidade Federal do Rio Grande do Sul, Porto Alegre.

DI GASPERO, G.; CIPRIANI, G.; MARRAZZO, M.T.; ANDREETTA, D.; PRADO CASTRO, M.J.; PETERLUNGER, E.; TESTOLIN, R. Isolation of (AC)n-microsatellites in Vitis vinifera $\mathrm{L}$. and analysis of genetic background in grapevines under marker assisted selection. Molecular Breeding, v.15, p.11-20, 2005.

DI GASPERO, G.; PETERLUNGER, E.; TESTOLIN, R.; EDWARDS, K.J.; CIPRIANI, G. Conservation of microsatellite loci within the genus Vitis. Theoretical and Applied Genetics, v.101, p.301-308, 2000.

GARRIDO, L. da R.; SÔNEGO, O.R.; GOMES, V.N. Fungos associados com o declínio e morte de videiras no Estado do Rio Grande do Sul. Fitopatologia Brasileira, v.29, p.332-324, 2004.

GOLDY, R.; ONOKPISE, O.U. Genetics and breeding. In: BASIOUNY, F.M.; HIMELRICK, D.G. (Ed.). Muscadine grapes. Blacksburg: ASHA, 2001. p.51-90.

KELLOW,A.V.; MCDONALD, G.; CORRIE, A.M.; HEESWIJCK, R.V. In vitro assessment of grapevine resistance to two populations of phylloxera from Australian vineyards. Australian Journal of Grape and Wine Research, v.8, p.109-116, 2002.

LEÃO, P.C. de S.; BORGES, R.M.E. Melhoramento genético da videira. Petrolina: Embrapa Semiárido, 2009. 61p. (Embrapa Semiárido. Documentos, 224).

LEÃO, P.C. de S.; MOTOIKE, S.Y. Genetic diversity in table grapes on RAPD and microsatellite markers. Pesquisa Agropecuária Brasileira, v.46, p.1035-1044, 2011.

LU, J.; LAMIKANRA, O. Barriers to intersubgeneric crosses between Muscadinia and Euvitis. HortScience, v.31, p.269-271, 1996.

Pesq. agropec. bras., Brasília, v.46, n.11, p.1480-1488, nov. 2011 
MERDINOGLU, D.; BUTTERLIN, G.; BEVILACQUA, L.; CHIQUET, V.; ADAM-BLONDON, A.F.; DECROOCQ, S. Development and characterization of a large set of microsatellite markers in grapevine (Vitis vinifera L.) suitable for multiplex PCR. Molecular Breeding, v.15, p.349-366, 2005.

NEAL, P.R.; ANDERSON, G.J. Does the 'old bag' make a good 'wind bag'?: comparison of four fabrics commonly used as exclusion bags in studies of pollination and reproductive biology. Annals of Botany, v.93, p.603-607, 2004.

OLMO, H.P. The potential role of (vinifera $\mathrm{x}$ rotundifolia) hybrids in grape variety improvement. Experientia, v.42, p.921-926, 1986.

REYNOLDS, A.G.; WARDLE, D.A. Rootstocks impact vine performance and fruit composition of grapes in British Columbia. HortTechnology, v.11, p.419-427, 2001.

RIAZ, S.; DANGL, G.S.; EDWARDS, K.J.; MEREDITH, C.J. A microsatellite marker based framework linkage map of Vitis vinifera L. Theoretical and Applied Genetics, v.108, p.864-872, 2004.

SCHUCK, M.R.; MOREIRA, F.M.; GUERRA, M.P.; VOLTOLINI, J.A.; GRANDO, M.S.; SILVA, A.L. da. Molecular characterization of grapevine from Santa Catarina, Brazil, using microsatellite markers. Pesquisa Agropecuária Brasileira, v.44, p.487-495, 2009.

SEFC, K.M.; LEFORT, F.; GRANDO, M.S.; SCOOT, K.D.; STEINKELLNER, H.; THOMAS, M.R.
Microsatellite markers for grapevine: a state of the art. In: ROUBELAKIS-ANGELAKIS, K.A. (Ed.). Molecular biology and biotechnology of the grapevines. Netherlands: Kluwer, 2001. p.433-463.

SEFC, K.M.; REGNER, F.; TURETSCHEK, E.; GLÖSSL, J.; STEINKELLNER, H. Identification of microsatellite sequences in Vitis riparia and their applicability for genotyping of different Vitis species. Genome, v.42, p.367-373, 1999.

SMITH, B.P. Genetic and molecular mapping studies on a population derived from Vitis vinifera $\mathbf{x}$ Muscadinia rotundifolia and genetic diversity of wild Muscadinia rotundifolia. 2010. 277p. Dissertation (Doctor) - University of California, Davis.

TAPIA, A.M.; CABEZAS, J.A.; CABELLO, F.; LACOMBE, T.; MARTÍNEZ-ZAPATER, J.M.; HINRICHSEN, P.; CERVERA, M.T. Determining the Spanish origin of representative ancient American grapevine varieties. American Journal of Enology and Viticulture, v.58, p.242-251, 2007.

THOMAS, M.R.; SCOTT, N.S. Microsatellite repeats in grapevine reveal DNA polymorphisms when analysed as sequence-tagged sites (STSs). Theoretical and Applied Genetics, v.86, p.985-990, 1993.

VASCONCELOS, M.C.; GREVEN, M.; WINEFIELD, C.S.; TROUGHT, M.C.T.; RAW, V. The flowering process of Vitis vinifera: a review. American Journal of Enology and Viticulture, v.60, p.411-434, 2009

WALKER, M.A.; LIDER, L.A.; GOHEEN, A.C.; OLMO, H.P. VR O39-16 grape rootstock. HortScience, v.26, p.1224-1225, 1991.

$\overline{\text { Received on July 22, } 2011 \text { and accepted on October 10, } 2011}$ 